\title{
Impact of hexenuronic acids on xylanase-aided bio-bleaching of chemical pulps
}

\author{
Anatoly A. Shatalov*, Helena Pereira \\ Centro de Estudos Florestais, Universidade Técnica de Lisboa, Instituto Superior de Agronomia, Tapada da Ajuda, 1349-017 Lisbon, Portugal
}

\section{A R T I C L E I N F O}

\section{Article history:}

Received 27 October 2008

Received in revised form 12 January 2009

Accepted 14 January 2009

Available online 23 February 2009

\section{Keywords:}

Hexenuronic acid

Xylanase

Bio-bleaching

Chemical pulp

Brightness

\begin{abstract}
A B S T R A C T
Hexenuronic acids (HexA) of hemicellulosic heteroxylan were shown to play important role in brightness development of chemical pulps during xylanase-aided bio-bleaching. Industrial wood (eucalypt) kraft pulp and a few non-wood (giant reed) organosolv pulps were pre-treated with commercial xylanase preparations (endo-1,4- $\beta$-xylanase activity; EC 3.2.1.8) and bleached by simplified bleaching sequence. The HexA performance was examined and compared with control (enzyme-free) samples. The xylanase-assisted direct brightening effect, noted immediately after an enzymatic stage, was proved to be caused by exclusive HexA removal with solubilized HexA-carrying xylooligosaccharide fractions. Aldohexa- and aldopentahexenuronic acids ( $\mathrm{Xyl}_{5}-\mathrm{HexA}$ and $\mathrm{Xyl}_{4}$-HexA) were found as predominant oligosaccharides, accounting for up to $65 \%$ of total acidic oligomers in enzymatic hydrolyzates. A strong positive correlation $\left(R^{2}=0.91\right)$ was established between further brightness improvement of xylanase-treated pulps during subsequent chemical bleaching (bleach boosting) and the content of HexA. This underlined the role of HexA as one of the key factors in definition of final brightness of bio-bleached pulps, determining to a large extent the bleaching efficiency of xylanase application as a whole.
\end{abstract}

() 2009 Elsevier Ltd. All rights reserved.

\section{Introduction}

Acidic heteroxylan (arabino-) 4-O-methylglucuronoxylan is a principal non-cellulosic polysaccharide of many industrially important wood and non-wood (agro-fiber crop) species. In alkaline pulping, 4-O-methylglucuronic acid (MeGlcA) side-groups attached to the xylan backbone are degraded by about $75-90 \%$ (Buchert et al., 1995, 1997a). The residual MeGlcA are partially converted to unsaturated 4-deoxy- $\beta$-L-threo-hex-4-enopyranosyluronic acid groups (hexenuronic acid or HexA) by $\beta$-elimination of methanol directly or via the intermediate product 4-O-methyliduronic acid (Clayton, 1963; Johansson and Samuelson, 1977; Simkovic et al., 1986). HexA was identified as a major uronic acid (UA) substituent both of the industrial kraft pulp and of some unconventional alkali-based organosolv pulps, accounting for 83$88 \%$ of total UA (Buchert et al., 1997a; Shatalov and Pereira, 2004).

The interest to HexA has quickened in the last decade, as a result of the revealed HexA capacity to affect negatively the following pulp bleaching and the properties of bleached pulps as well (Jiang et al., 2000). In fact, the bi-functionality of HexA, i.e., the presence of enol ether and unsaturated carboxylic acid group, makes it an easy target for both electrophilic and nucleophilic attacks during bleaching. The HexA reactions with electrophilic bleaching chemicals, such as chlorine dioxide, ozone and peracids, increase consumption of these chemicals (Vuorinen et al., 1999).

\footnotetext{
* Corresponding author. Tel.: +351 21363 4662; fax: +351213645000.

E-mail address: anatoly@isa.utl.pt (A.A. Shatalov).
}

The capacity of HexA to bind heavy metal ions affects indirectly consumption of other bleaching chemicals, such as hydrogen peroxide (Devenyns and Chauveheid, 1997). Oxidative degradation of HexA (e.g., during ozonation) causes formation of calcium oxalate deposits in the bleaching equipment (Elsander et al., 2000). HexA consume permanganate during the standard procedure of kappa number determination, commonly used (particularly in industry) for lignin quantification in pulps (Li and Gellerstedt, 1997). Finally, the HexA can modify optical properties of bleached pulps by decreasing brightness and increasing brightness reversion (Buchert et al., 1997b).

The enzymatic pulp pre-treatment with highly specific hemicellulolytic enzymes (particularly with endo-1,4- $\beta$-xylanase activity, EC 3.2.1.8) before chemical bleaching (so-called bio-bleaching) has attracted considerable recent interest as a potential environmentally benign biotechnological approach. Xylanases allow to reduce consumption of active bleaching chemicals (particularly the chlorine-based) and to increase the final brightness ceiling of bleached pulps (Tolan et al., 1996; Yang et al., 1992). The beneficial effect of xylanases on kraft pulp bleaching is attributed to the selective hydrolysis of xylan re-precipitated on the fiber surface and therefore improving fiber permeability to bleaching reagents and degradation products (Kantelinen et al., 1993), or to the increased extractability of lignin-carbohydrate complexes (LCC), what facilitates the pulp delignification during subsequent chemical bleaching steps (Paice et al., 1992).

Only limited published data are available about the effect of HexA on the bleaching performance of xylanases, whereas this 
kind of information is of considerable practical importance since it allows defining the contribution of carbohydrate-derived chromophores in the bleaching mechanism of xylanases, thereby assuming the better control of brightness development during the entire bleaching process. In the scale of pulp and paper industry, as one of the most capital-intensive "heavy" industries in the world, even moderate change (increase) in pulp brightness can have tremendous economical effect.

To assess the role of HexA in bio-bleaching of chemical pulps, the fate of HexA during xylanase-aided bleaching of different pulps has been studied and correlated with brightness development after each bleaching stage. The results of this study are reported in the present paper.

\section{Experimental}

\subsection{Materials}

Industrial unbleached eucalypt (Eucalyptus globulus L.) kraft pulp (Portucel Mill, Portugal) and three non-wood (Arundo donax L.) organosolv pulps (alkali-sulfite-anthraquinone-methanol or ASAM, alkali-anthraquinone-methanol or Organocell and Ethanol-alkali) were used in bio-bleaching experiments. The kraft pulp had $41.3 \%$ ISO brightness, $3.4 \%$ of residual lignin and $1348 \mathrm{~mL} \mathrm{~g}^{-1}$ intrinsic viscosity. The detailed description of organosolv pulps preparation as well as the pulp properties have been published elsewhere (Shatalov and Pereira, 2001, 2005).

Commercial xylanase preparations Ecopulp ${ }^{\circledR}$ TX-200A and Pulpzyme ${ }^{\circledR}$ HC were obtained from AB Enzymes (Germany) and Novozymes A/S (Denmark), respectively. Ecopulp TX-200A is a thermostable EC 3.2.1.8 xylanase preparation produced by a strain of non-pathogenic fungi and specially designed to improve the bleachability of woody kraft pulps at high temperature. The xylanase activity of the product was standardized by the supplier to $190,000 \mathrm{TXU} \mathrm{g}^{-1}$. One thermo-xylanase unit (TXU) is defined as the amount of enzyme that produces reducing carbohydrates with a reducing power corresponding to one nmol xylose from birch xylan in one second under assay conditions. The DNSxylanase assay was used to determine xylanase activity in citrate phosphate buffer at pH 7 (Bailey et al., 1992). Pulpzyme HC is an EC 3.2.1.8. xylanase activity produced by submerged fermentation of a genetically modified Bacillus microorganism. The product was standardized to $1000 \mathrm{AXU} \mathrm{g}^{-1}$ (Xylanase Unit). One xylanase unit was defined as the amount of enzyme which under standard conditions ( $\mathrm{pH} 9.0,50^{\circ} \mathrm{C}, 30 \mathrm{~min}$ incubation) releases a defined amount of dye from dyed xylan (remazol-stained wheat arabinoxylan).

All other chemicals (analytical grade purity) were purchased from Sigma-Aldrich, Fluka and Riedel-de-Haen companies.

\subsection{Xylanase pre-treatment and bleaching}

The enzymes were applied within the range of recommended conditions. $30 \mathrm{~g}$ (on oven-dry basis) of unbleached kraft pulp was thoroughly hand-mixed with xylanase solution $\left(76 \mathrm{XU} \mathrm{g}^{-1}\right.$ of Ecopulp or $1 \mathrm{XU} \mathrm{g}^{-1}$ of Pulpzyme) at $10 \%$ consistency and $\mathrm{pH} 7$ and incubated for $3 \mathrm{~h}$ at the required temperature of $65^{\circ} \mathrm{C}$ or $60^{\circ} \mathrm{C}$ for Ecopulp and Pulpzyme, respectively. After enzymatic hydrolysis, the spent filtrate was collected for subsequent analysis, and the pulps were carefully washed with deionised water. The control samples (enzyme-free) were treated by exactly the same way.

Hydrogen peroxide bleaching of xylanase pre-treated pulps was performed in the double-layer sealed plastic bags plunged into an agitated water bath with controlled heating using conditions previously described elsewhere (Shatalov and Pereira, 2005).

\subsection{Electrospray ionization mass spectrometry (ESI-MS)}

The ESI-MS analysis was carried out on a Micromass Quattro LC mass spectrometer. The aliquot of undiluted filtrate after enzymatic stage was adjusted to a concentration of ca. $50 \mathrm{ng} \mu \mathrm{L}^{-1}$ of dry matter in $3: 1 \mathrm{CH}_{3} \mathrm{OH}-\mathrm{CH}_{2} \mathrm{Cl}_{2}$ solution. Ionizing agent (ammonium hydroxide) was added to final concentration of $0.2 \% \mathrm{NH}_{4} \mathrm{OH}$. Sample was injected at a flow rate of $10 \mu \mathrm{L} \mathrm{min}^{-1}$ into the electrospray source coupled with triple-quadruple mass spectrometer. To optimize ion intensity, the voltage range of $40-50 \mathrm{~V}$ was used in the source sampling cone.

\subsection{Analytical methods}

Carbohydrate composition of pulps was determined by GC as the alditol-acetate derivatives of monosaccharides (Shatalov and Pereira, 2007) after pulp Saeman hydrolysis (Saeman et al., 1963).

Hexenuronic acid groups in pulps were quantified by selective hydrolysis in formic acid-sodium formate buffer followed by UVspectroscopy (Shimadzu, UV-160A) of the formed 2-furoic acid at $245 \mathrm{~nm}$ (Vuorinen et al., 1999). The same conditions were used for preparation of HexA-free pulps.

Residual lignin content was determined as a Klason and acidsoluble lignin according to T $222 \mathrm{om}-88$ and UM 250 TAPPI standards. Pulp viscosity was measured in cupri-ethylenediamine (CED) solution according to SCAN-CM 15:88 standard. Handsheets for reflectance testing of pulps were prepared according to T 272 om-92 TAPPI standard. Pulp optical properties, i.e. ISO brightness and DIN 6167 C/2 yellowness index, were measured by CM-3630 Spectrophotometer (Minolta).

At least three replicate analyses were performed in all cases.

\section{Results and discussion}

\subsection{Effect of HexA on xylanase-assisted direct brightening}

The primary purpose of xylanase pre-treatment in pulp bleaching is to improve pulp bleachability, basically assumed as a capacity to brightness (or whiteness) development in the subsequent chemical bleaching stages, i.e., bleach boosting. However, as it was noted before (Wong et al., 1996; Yang and Eriksson, 1992), the bleaching effect (direct pulp brightening) can be already observed immediately after an enzymatic stage and causes some change in the pulp optical properties. Obviously, the enzymatic removal of both the lignin-derived (as part of the lignin-carbohydrate complex, LCC) and the carbohydrate-derived chromophores can cause the change in pulp brightness.

To examine the HexA effect on direct pulp brightening, the unbleached industrial eucalypt (E. globulus L.) kraft pulp as well as three non-woody (giant reed or A. donax L.) organosolv (organic solvent-based) pulps (ASAM, Organocell and Ethanol-alkali) were treated with commercial xylanase preparations (endo-1,4- $\beta$-xylanase activity; EC 3.2.1.8) and the change in pulp properties was defined in comparison with control (enzyme-free) samples.

As expected, the xylanase treatment caused a direct pulp brightening observed with all of the tested pulps (Table 1). However, under identical reaction conditions, the brightness development of eucalypt kraft pulp was better in spite of lower intensity of enzymatic hydrolysis (xylose loss $1.6 \%$ vs. $4.8-6.3 \%$ for kraft and organosolv pulps, respectively). The fairly close degree of delignification shown for different pulps (as a result of the mentioned LCC degradation with removal of some lignin groups and ligninassociated chromophores) cannot explain the scatter of the experimental data on brightness development. At the same time, a rather good agreement can be observed between change in bright- 
Table 1

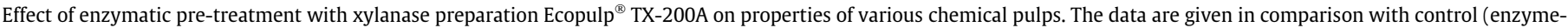
free) samples.

\begin{tabular}{|c|c|c|c|c|c|c|c|c|c|c|c|c|}
\hline & \multicolumn{3}{|c|}{ Eucalypt kraft } & \multicolumn{3}{|c|}{ Reed ethanol-alkali } & \multicolumn{3}{|c|}{ Reed organocell } & \multicolumn{3}{|c|}{ Reed ASAM } \\
\hline & Control & Enzyme & $\Delta^{\mathrm{a}}$ & Control & Enzyme & $\Delta$ & Control & Enzyme & $\Delta$ & Control & Enzyme & $\Delta$ \\
\hline Brightness (\% ISO) & 42.4 & 43.9 & 1.5 & 41.5 & 42.7 & 1.2 & 33.0 & 34.0 & 1.0 & 38.9 & 39.5 & 0.6 \\
\hline $\operatorname{HexA}(\mu \mathrm{mol} / \mathrm{g})^{\mathrm{b}}$ & 50.45 & 43.13 & 7.32 & 27.69 & 23.21 & 4.48 & 16.78 & 12.62 & 4.16 & 7.21 & 6.16 & 1.05 \\
\hline Lignin $(\% \text { odp })^{c}$ & 3.33 & 2.98 & 0.35 & 3.54 & 3.07 & 0.47 & 2.64 & 2.28 & 0.36 & 3.81 & 3.36 & 0.45 \\
\hline Xylose $(\% \text { odp })^{\mathrm{c}}$ & 17.10 & 15.56 & 1.54 & 29.01 & 24.18 & 4.83 & 33.20 & 26.92 & 6.28 & 26.00 & 20.74 & 5.26 \\
\hline
\end{tabular}

${ }^{a}$ Change in property.

b The $\mu \mathrm{mol}$ of HexA per gram of pulp.

c Percentage on oven-dry pulp.

ness and HexA removal. The strong positive correlation $\left(R^{2}=0.97\right)$ was established between gain in brightness and HexA loss during xylanase treatment of different chemical pulps, thereby pointing to HexA as an important factor for direct pulp brightening. Since the loss of HexA during xylanase treatment is presumably caused by enzymatic solubilization of acidic xylooligosaccharide fractions, the elevated HexA removal from eucalypt kraft pulp is somewhat surprising in view of lower rate of enzymatic hydrolysis. The higher degree of HexA substitution in eucalypt heteroxylan in comparison with reed $\left(50.5 \mu \mathrm{mol} \mathrm{g}^{-1}\right.$ vs. $7.2-27.7 \mu \mathrm{mol} \mathrm{g}^{-1}$ for eucalypt kraft and reed organosolv pulps, respectively) can explain this apparent discrepancy in experimental data.

To check the assumption on HexA losses with solubilized xylooligosaccharide fractions, the undiluted filtrates after an enzymatic hydrolysis were analyzed by negative mode ESI-MS. Among a group of neutral oligosaccharide fragments $\left(\mathrm{Xyl}_{2-5}\right)$ observed as the corresponding deprotonated molecules $[\mathrm{M}-\mathrm{H}]^{-}$at $\mathrm{m} / \mathrm{z} 281$, 413, 545 and 677, the long-chain acidic xylooligosaccharides (aldouronic acids) with degree of polymerization (DP) from 4 to 10 were also identified. It is remarkable that a couple of acidic oligomers, i.e. HexA-carrying aldohexenuronic acid and MeGlcA-carrying aldoglucuronic acid, were observed for each DP (Tables 2 and 3). All identified $\mathrm{Xyl}_{3-9} \mathrm{HexA}$ acidic oligomers (at $m / z 571,703$, $835,967,1099,1231$ and 1363) were much more abundant (up to 4 times more) than their aldoglucuronic acid analogs in eucalypt kraft and reed Ethanol-alkali and Organocell pulps. In contrary, the $\mathrm{Xyl}_{3-9}$ MeGlcA oligomers (at $m / z$ 603, 735, 867, 999, 1131, 1263 and 1395 ) were more abundant in ASAM pulp. The low HexA content in ASAM pulp and poor HexA removal during enzymatic hydrolysis (Table 1) correlates well with data of ESI-MS analysis.

Table 2

ESI-MS data on acidic xylooligosaccharide (XOS) fragments released from eucalypt (E. globulus L.) kraft pulp during enzymatic hydrolysis with xylanase preparations Ecopulp $^{\circledR}$ TX-200A and Pulpzyme ${ }^{\circledR}$ HC.

\begin{tabular}{|c|c|c|c|}
\hline \multirow[t]{2}{*}{$m / z$} & \multirow[t]{2}{*}{ Suggested XOS structure } & \multicolumn{2}{|c|}{ Relative abundance (\%) } \\
\hline & & Ecopulp & Pulpzyme \\
\hline 571 & $\mathrm{Xyl}_{3}-\mathrm{HexA}$ & 1.3 & 1.5 \\
\hline 603 & $\mathrm{Xyl}_{3}-\mathrm{MeGlcA}$ & 0.7 & 1.1 \\
\hline 703 & $\mathrm{Xyl}_{4}-\mathrm{HexA}$ & 20.3 & 13.0 \\
\hline 735 & $\mathrm{Xyl}_{4}-\mathrm{MeGlcA}$ & 19.1 & 15.9 \\
\hline 835 & $\mathrm{Xyl}_{5}-\mathrm{HexA}$ & 20.6 & 19.7 \\
\hline 867 & $\mathrm{Xyl}_{5}-\mathrm{MeGlcA}$ & 16.2 & 14.5 \\
\hline 967 & $\mathrm{Xyl}_{6}-\mathrm{HexA}$ & 7.6 & 9.4 \\
\hline 999 & $\mathrm{Xyl}_{6}-\mathrm{MeGlcA}$ & 6.8 & 7.0 \\
\hline 1029 & $\mathrm{Xyl}_{5}-\mathrm{MeGlcA-Gal}$ & 1.3 & 1.1 \\
\hline 1099 & $\mathrm{Xyl}_{7}-\mathrm{HexA}$ & 1.9 & 5.6 \\
\hline 1131 & $\mathrm{Xyl}_{7}-\mathrm{MeGlcA}$ & 1.8 & 4.0 \\
\hline 1161 & $\mathrm{Xyl}_{6}-\mathrm{MeGlcA-Gal}$ & 0.9 & 0.8 \\
\hline 1231 & $\mathrm{Xyl}_{8}-\mathrm{HexA}$ & 0.5 & 2.2 \\
\hline 1263 & $\mathrm{Xyl}_{8}-\mathrm{MeGlcA}$ & 0.4 & 1.9 \\
\hline 1293 & $\mathrm{Xyl}_{7}-\mathrm{MeGlcA}-\mathrm{Gal}$ & 0.4 & 0.6 \\
\hline 1363 & $\mathrm{Xyl}_{9}-\mathrm{HexA}$ & 0.1 & 0.9 \\
\hline 1395 & Xyl9-MeGlcA & 0.1 & 0.8 \\
\hline
\end{tabular}

Table 3

ESI-MS data on acidic xylooligosaccharide (XOS) fragments released from giant reed (A. donax L.) organosolv pulps during enzymatic hydrolysis with xylanase preparation Ecopulp ${ }^{\circledR}$ TX-200A.

\begin{tabular}{lllll}
\hline $\mathrm{m} / z$ & Suggested XOS structure & \multicolumn{3}{l}{ Relative abundance $(\%)$} \\
\cline { 3 - 5 } & & Ethanol-alkali & Organocell & ASAM \\
\hline 571 & $\mathrm{Xyl}_{3}$-HexA & 2.3 & 3.1 & 1.2 \\
603 & $\mathrm{Xyl}_{3}$-MeGlcA & 0.9 & 0.8 & 2.6 \\
703 & $\mathrm{Xyl}_{4}$-HexA & 40.2 & 27.5 & 2.9 \\
735 & $\mathrm{Xyl}_{4}$-MeGlcA & 9.9 & 12.9 & 36.3 \\
835 & $\mathrm{Xyl}_{5}$-HexA & 24.8 & 23.0 & 2.3 \\
867 & $\mathrm{Xyl}_{5}$-MeGlcA & 6.8 & 10.7 & 30.0 \\
967 & $\mathrm{Xyl}_{6}$-HexA & 7.2 & 9.6 & 1.7 \\
999 & $\mathrm{Xyl}_{6}-$ MeGlcA & 1.8 & 4.8 & 13.8 \\
1099 & $\mathrm{Xyl}_{7}-$ HexA & 5.0 & 5.3 & Traces \\
1131 & $\mathrm{Xyl}_{7}-$ MeGlcA & 1.1 & 2.2 & 9.2 \\
\hline
\end{tabular}

Some additional group of acidic xylooligosaccharide fragments $\mathrm{Xyl}_{5-7}$-MeGlcA-Gal was revealed in ESI-MS spectrum of eucalypt kraft pulp (Table 2), confirming the previously revealed quite original structure of E. globulus heteroxylan (Shatalov et al., 1999), and taking into account the structural changes of this polysaccharide during kraft pulping (Shatalov and Pereira, 2000). The ions assignment was also supported by data on carbohydrate composition of the xylanase-treated pulp, which showed the removal solely of xylosyl, galactosyl and glucuronosyl monosaccharide residues during enzymatic hydrolysis. No evident proofs confirming incorporation of other glycosyl residues (e.g., glucose Glc) into the chemical structure of heteroxylan were observed.

The ESI-MS spectra of the control (enzyme-free) samples processed under essentially identical reaction conditions did not reveal any carbohydrate oligomers in the reaction solution, underlining thereby the exclusively enzyme-assisted release of acidic xylooligosaccharide fractions.

The suggested structure of the HexA-carrying xylooligosaccharides was confirmed by tandem electrospray ionization mass spectrometry (ESI-MS/MS). The MS/MS spectra of the predominant ions observed in the ESI-MS spectra at $\mathrm{m} / \mathrm{z} 703$ and 835, attributed respectively to deprotonated molecules of $\mathrm{Xyl}_{4} \mathrm{HexA}$ and $\mathrm{Xyl}_{5} \mathrm{HexA}$, are shown in Fig. 1. The similar fragmentation pathways can be noted for both oligosaccharides. The stepwise fragmentation of the xylosyl backbone from the reducing end, as a result of selective deprotonation of anomeric carbon (Garozzo et al., 1990; Spengler et al., 1990), leads to successive loss of xylosyl residues $\mathrm{Xyl}_{1-4}$ (observed at $m / z 131,263,395$ and 527) and gives origin to fragment ions at $m / z 305,437,569$ and 703, corresponding to $\mathrm{Xyl}_{1-4} \mathrm{HexA}$ oligomers. The presence of ions $\mathrm{Xyl}_{3}$ at $\mathrm{m} / z 395$ (in the upper spectrum) and $\mathrm{Xyl}_{4}$ at $\mathrm{m} / \mathrm{z} 527$ (in the bottom spectrum) suggests the attachment of the substituting residue (HexA) at the reducing end of the oligosaccharide chain.

The abundant fragment ions observed at $m / z 643$ (upper spectrum) and $m / z 775$ (bottom spectrum) due to loss of $60 \mathrm{Da}$ from 


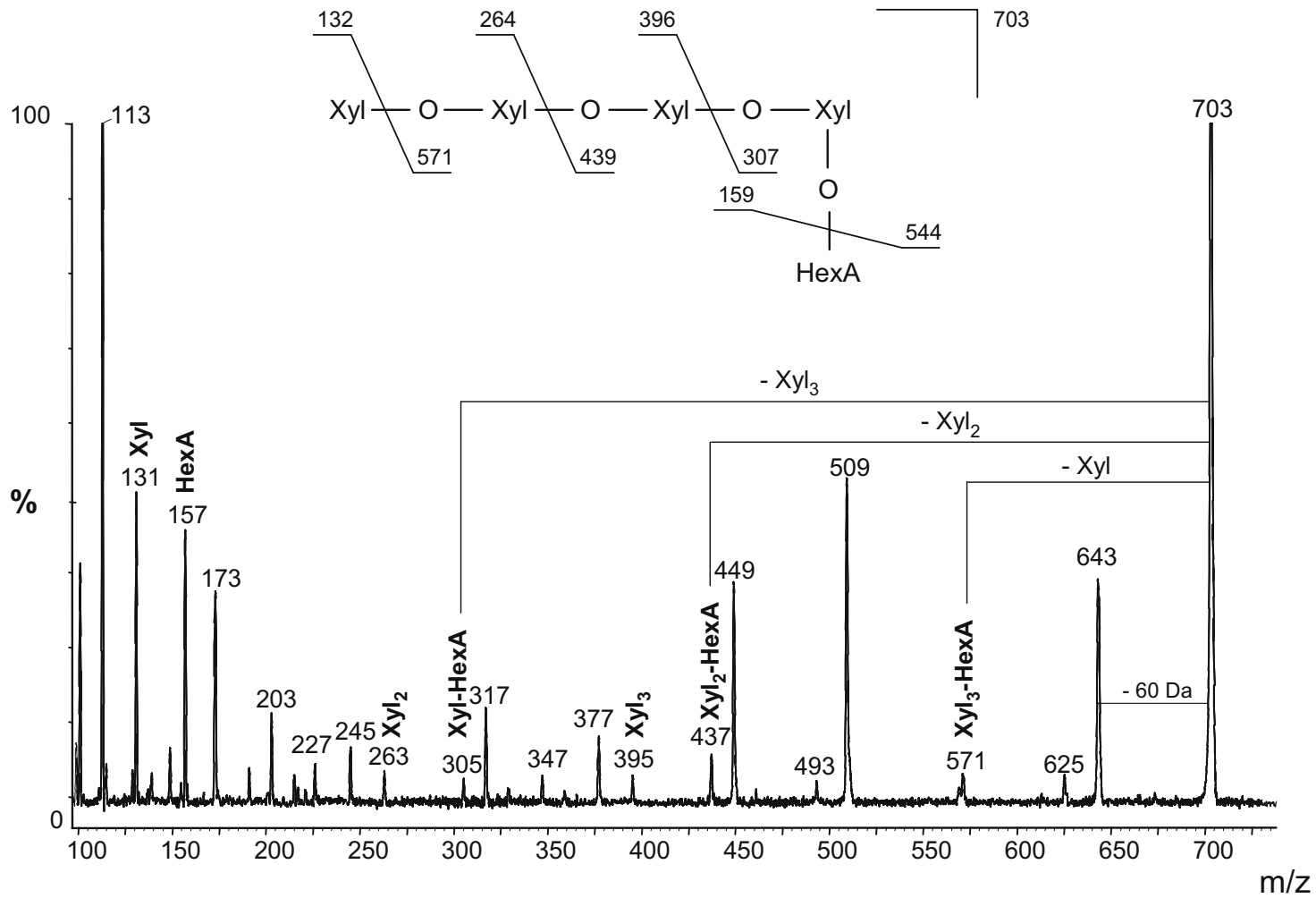

03

$\mathrm{m} / \mathrm{z}$

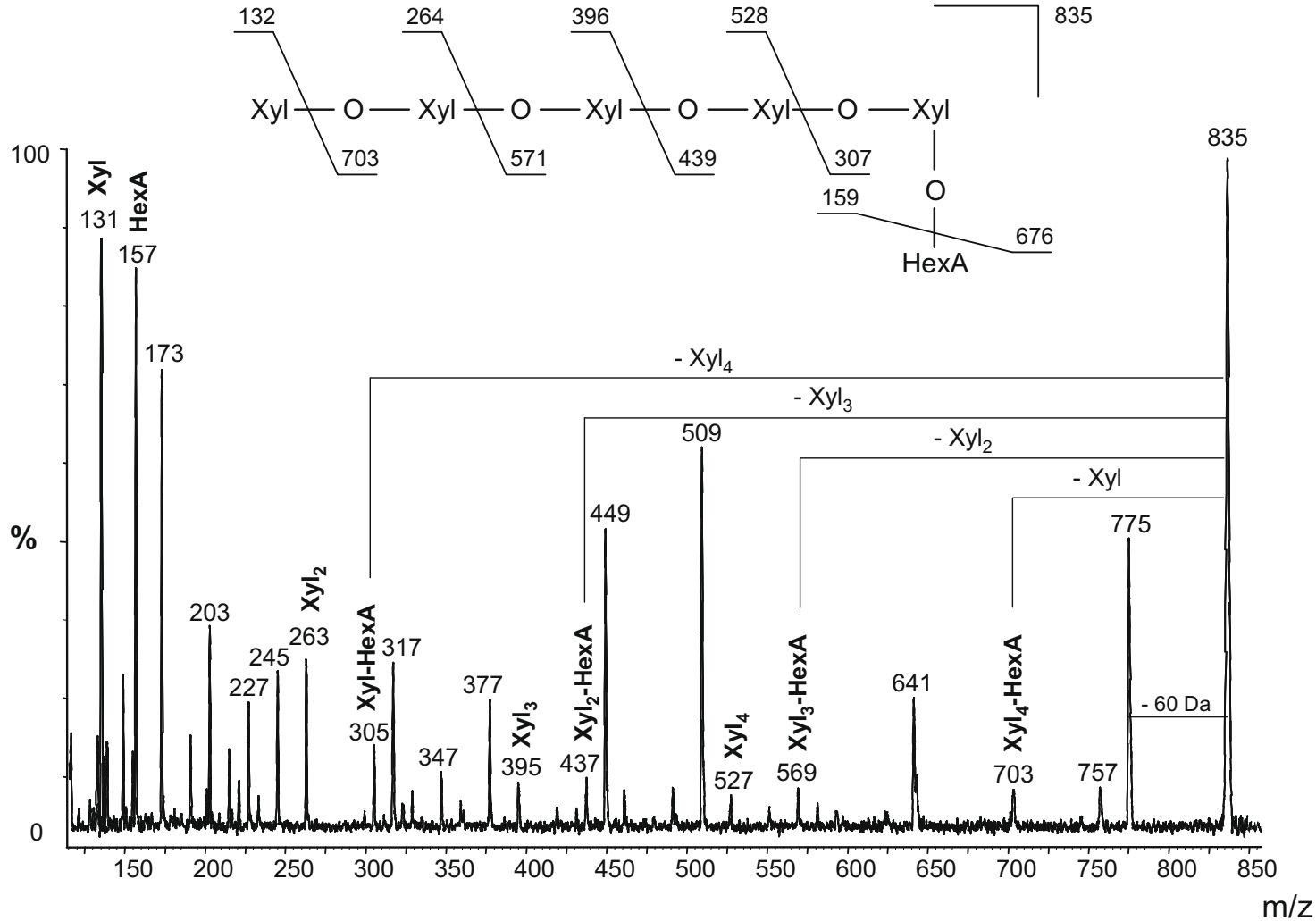

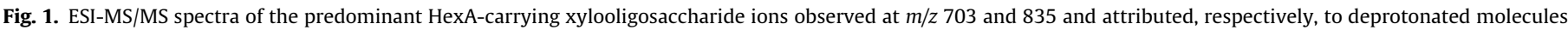

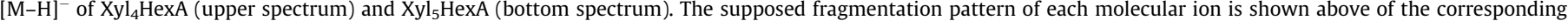
spectrum.

the precursor ions of $\mathrm{Xyl}_{4} \mathrm{HexA}$ and $\mathrm{Xyl}_{5} \mathrm{HexA}$ (followed by successive loss of 18 Da with formation of respective ions at $m / z 625$ and 757) can be attributed to a cross-ring fragmentation of the xylosyl residue at the reducing end of oligomers (Mulroney et al., 1995). The following successive loss of xylosyl residues $\left(\mathrm{Xyl}_{1-4}\right)$ leads to formation of fragment ions at $m / z 641,509,377$ and 245 , which 
are the subject of further cross-ring fragmentation (60 Da loss) with formation of the ions at $m / z 581$ (not marked), 449, 317 and 185 (not marked).

To define contribution of HexA-caused brightening to total xylanase-assisted brightness improvement, assuming additional effect on brightness from other chromophores (such as lignin), the selective removal of HexA from eucalypt kraft pulp was performed before xylanase treatment (Vuorinen et al., 1999). The HexA-free pulp was then treated with xylanase preparations and examined on change in optical properties before and after enzymatic treatment. As can be seen from Table 4, the preliminary HexA removal caused increase in pulp brightness from 42.7\% ISO to $44.4 \%$ ISO. The following xylanase treatment of HexA-free pulp by two different xylanase preparations did not affect pulp brightness (44.6\% ISO and 44.3\% ISO brightness of HexA-free pulp after xylanase treatment with Ecopulp and Pulpzyme, respectively). It is remarkable that the brightness improvement due to selective HexA removal was found to be practically the same to that achieved due to direct brightening after xylanase treatment (see brightness of enzyme-treated initial and HexA-free pulps). Based on these results, it is safe to assume that the direct brightening effect observed during xylanase treatment of chemical pulps is primarily caused by the enzymatic removal of hexenuronic acids (HexA), even though some delignification reaction takes place.

\subsection{Effect of HexA on xylanase bleach boosting}

A multi-stage hydrogen peroxide bleaching was chosen as a simplified model to assess the effect of HexA on xylanase bleach boosting. Hydrogen peroxide is a fairly effective chlorine-free oxidative chemical which is widely used as an integral part of all modern TCF bleaching sequences (Süss and Nimmerfroh, 1993). The enzymatically pre-treated eucalypt kraft and reed organosolv pulps were bleached by either one single or three consecutive peroxide stages under identical process conditions. The fate of HexA during bleaching was followed in comparison with control (enzyme-free) samples and correlated with brightness development.

As can be seen from Table 5, even single-step hydrogen peroxide bleaching causes additional brightness improvement of enzymatically pre-treated pulps up to $3 \%$ ISO in comparison with control, as a result of xylanase bleach boosting effect. The gain in brightness of pre-treated pulps is accompanied by additional loss in lignin and HexA. Considering the low reactivity of HexA with hydrogen peroxide (Jiang et al., 2000), the noted HexA losses are obviously caused by indirect HexA removal with degraded heteroxylan under alkaline bleaching conditions. It is easy to see that the change in brightness correlates well with the change in HexA content. The elevated HexA removal from kraft, Ethanol-alkali and, particularly, Organocell pulps agrees with their better bright-

Table 4

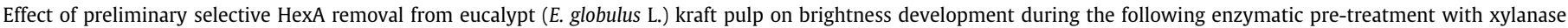
preparations Ecopulp ${ }^{\circledR}$ TX-200A and Pulpzyme ${ }^{\circledR}$ HC.

\begin{tabular}{|c|c|c|c|c|c|c|}
\hline & \multicolumn{2}{|l|}{ Control } & \multicolumn{2}{|l|}{ Ecopulp } & \multicolumn{2}{|l|}{ Pulpzyme } \\
\hline & Brightness (\% ISO) & Yellowness index & Brightness (\% ISO) & Yellowness index & Brightness (\% ISO) & Yellowness index \\
\hline Initial pulp & $42.7 \pm 0.07$ & $34.2 \pm 0.05$ & $44.6 \pm 0.08$ & $32.3 \pm 0.07$ & $44.0 \pm 0.05$ & $33.1 \pm 0.02$ \\
\hline HexA-free pulp & $44.4 \pm 0.03$ & $32.3 \pm 0.08$ & $44.6 \pm 0.02$ & $31.6 \pm 0.03$ & $44.3 \pm 0.02$ & $32.2 \pm 0.02$ \\
\hline
\end{tabular}

Table 5

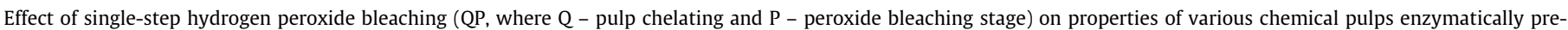
treated with Ecopulp ${ }^{\circledR}$ TX-200A xylanase preparation. The data are given in comparison with control (enzyme-free) samples.

\begin{tabular}{|c|c|c|c|c|c|c|c|c|c|c|c|c|}
\hline & \multicolumn{3}{|c|}{ Eucalypt kraft } & \multicolumn{3}{|c|}{ Reed ethanol-alkali } & \multicolumn{3}{|c|}{ Reed organocell } & \multicolumn{3}{|c|}{ Reed ASAM } \\
\hline & Control & Enzyme & $\Delta^{\mathrm{a}}$ & Control & Enzyme & $\Delta$ & Control & Enzyme & $\Delta$ & Control & Enzyme & $\Delta$ \\
\hline Brightness (\% ISO) & 75.8 & 77.9 & 2.1 & 68.1 & 70.2 & 2.1 & 61.5 & 64.4 & 2.9 & 61.9 & 63.4 & 1.5 \\
\hline $\operatorname{HexA}(\mu \mathrm{mol} / \mathrm{g})^{\mathrm{b}}$ & 44.13 & 34.69 & 9.44 & 23.35 & 13.54 & 9.81 & 13.95 & 3.15 & 10.80 & 5.42 & 3.41 & 2.01 \\
\hline Lignin $(\% \text { odp })^{\mathrm{c}}$ & 1.95 & 1.57 & 0.38 & 2.84 & 2.55 & 0.29 & 2.05 & 1.75 & 0.30 & 2.87 & 2.65 & 0.22 \\
\hline
\end{tabular}

a Change in property.

b The $\mu$ mol of HexA per gram of pulp.

c Percentage on oven-dry pulp.

Table 6

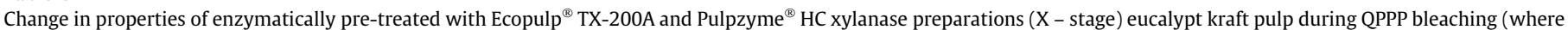
$\mathrm{Q}$ - pulp chelating; P - hydrogen peroxide bleaching stage). The data are given in comparison with control (enzyme-free) samples.

\begin{tabular}{|c|c|c|c|c|c|c|c|c|c|c|c|c|}
\hline \multirow{2}{*}{ 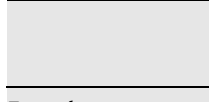 } & \multicolumn{3}{|l|}{$\mathrm{X}$} & \multicolumn{3}{|l|}{ XQP } & \multicolumn{3}{|l|}{ XQPP } & \multicolumn{3}{|l|}{ XQPPP } \\
\hline & Control & Enzyme & $\Delta^{\mathrm{a}}$ & Control & Enzyme & $\Delta$ & Control & Enzyme & $\Delta$ & Control & Enzyme & $\Delta$ \\
\hline \multicolumn{13}{|l|}{ Ecopulp } \\
\hline Brightness (\% ISO) & 42.4 & 43.9 & 1.5 & 75.8 & 77.9 & 2.1 & 81.2 & 82.9 & 1.7 & 85.0 & 86.4 & 1.4 \\
\hline $\operatorname{HexA}(\mu \mathrm{mol} / \mathrm{g})^{\mathrm{b}}$ & 50.45 & 43.13 & 7.32 & 44.13 & 34.69 & 9.44 & 39.81 & 32.19 & 7.62 & 36.60 & 30.63 & 5.97 \\
\hline Lignin $(\% \text { odp })^{c}$ & 3.33 & 2.98 & 0.35 & 1.95 & 1.57 & 0.38 & 1.63 & 1.24 & 0.39 & 1.40 & 1.01 & 0.39 \\
\hline \multicolumn{13}{|l|}{ Pulpzyme } \\
\hline Brightness (\% ISO) & 42.0 & 43.2 & 1.2 & 74.8 & 76.9 & 2.1 & 80.1 & 81.5 & 1.4 & 84.5 & 85.7 & 1.2 \\
\hline HexA $(\mu \mathrm{mol} / \mathrm{g})^{\mathrm{b}}$ & 49.16 & 43.69 & 5.47 & 44.04 & 35.92 & 8.12 & 40.19 & 33.77 & 6.42 & 37.14 & 31.88 & 5.26 \\
\hline Lignin $(\% \text { odp })^{c}$ & 3.06 & 2.85 & 0.21 & 1.87 & 1.60 & 0.27 & 1.61 & 1.30 & 0.31 & 1.29 & 1.03 & 0.31 \\
\hline
\end{tabular}

\footnotetext{
a Change in property.

b The $\mu \mathrm{mol}$ of HexA per gram of pulp.

c Percentage on oven-dry pulp.
} 
ness improvement in comparison with ASAM pulp. The scatter data on lignin content add some complexity to the data interpretation. No confident correlation was found between brightness improvement and lignin removal. Nonetheless, similar to HexA, the general tendency of increased brightness development under increased lignin removal can be observed, pointing to joint contribution of both types of chromophores to pulp brightening during bleaching.

It is of special interest to follow the HexA-to-brightness performance with bleaching progress to high brightness values, nearing the "fully bleached pulp". To assess this objective, the enzymatically pre-treated (with both Ecopulp and Pulpzyme xylanase preparations) eucalypt kraft pulp was bleached by model QPPP sequence to get the final brightness of ca. $86 \%$ ISO. The principal results are summarized in Table 6. As evident, both xylanases exhibit the highest bleach boosting efficiency (maximal brightness improvement in comparison with control) only at the beginning of bleaching after the first peroxide stage. The achieved gain in brightness is thereafter gradually reduced with each subsequent P-stage, similar to previously reported observation of Yang and Eriksson (1992). Obviously, this decrease in brightening can not be associated with change in lignin (lignin-derived chromophores) content in bleached pulps. The rate of delignification of both xylanase-treated pulps increases continuously along the bleaching leading to additional (over the control) lignin removal after each subsequent bleaching stage, as a result of facilitated accessibility of xylanase-treated pulps to active chemicals in bleaching solution. In contrast, the HexA performance during QPPP bleaching was found to be in excellent agreement with the bleaching profile of brightness. Similar to the latter, the maximal HexA losses were detected after the first bleaching stage with a tendency to continuous diminishing by the end of the bleaching sequence. A quite strong positive correlation $\left(R^{2}=0.91\right)$ can be observed between data on HexA losses and brightness improvement (over the control) during xylanase-aided bleaching of eucalypt kraft pulp (Fig. 2). The HexA play therefore the role of one of the controlling factors in the definition of final brightness of xylanase pre-treated pulps during chemical bleaching, and determine to a large extent the bleaching efficiency of xylanase application as a whole. The extent of HexA impact on bleaching results will, obviously, depend on their abundance in pulp (i.e., the plant species and the pulping process) and the bleaching sequence used (i.e., the kind of active bleaching chemicals).

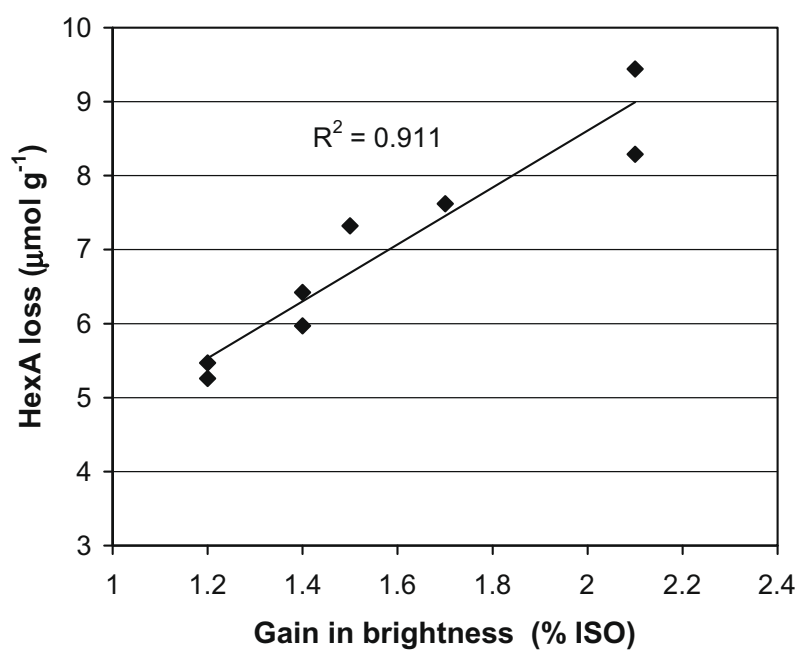

Fig. 2. Gain in brightness as a function of HexA loss during three-stage hydrogen peroxide bleaching of enzymatically pre-treated (with both Ecopulp ${ }^{\circledR}$ TX-200A and Pulpzyme ${ }^{\circledR}$ HC xylanase preparations) eucalypt kraft pulp. The data are given in comparison with control (enzyme-free) samples.

\section{Conclusions}

The carbohydrate-derived chromophores have a pronounced effect on brightness development of chemical pulps during xylanaseaided bio-bleaching. The xylanase-assisted direct pulp brightening was shown to be primarily caused by HexA removal with solubilized xylooligosaccharide fractions. Strong positive correlation was established between xylanase bleach boosting effect and bleaching profile of HexA. That underlined the important role of HexA in the definition of final brightness of bio-bleached pulps and pointed to HexA as one of the principal factors affecting the bleaching efficiency of xylanase application as a whole.

\section{Acknowledgements}

The financial support of the Fundação para a Ciência e a Tecnologia (FCT, Portugal) is gratefully acknowledged. The authors thank Mr. Pasi Taipalus (AB Enzymes, Finland) and Mr. Eugen Muller (Novozymes Deutschland $\mathrm{GmbH}$ ) for providing enzymes and Dr. José Graça (CEF, ISA, UTL) for kind technical assistance in ESI-MS analysis.

\section{References}

Bailey, M.J., Biely, P., Poutanen, K., 1992. Interlaboratory testing of methods for assay of xylanases activity. J. Biotechnol. 23, 257-270.

Buchert, J., Teleman, A., Harjunpää, V., Tenkanen, M., Viikari, L., Vuorinen, T., 1995 Effect of cooking and bleaching on the structure of xylan in conventional pine kraft pulp. Tappi J. 78, 125-130.

Buchert, J., Laine, J., Tenkanen, M., Vuorinen, T., Viikari, L., 1997a. Characterization of uronic acids during kraft and superbatch pulping. In: Nineth International Symposium on Wood and Pulp Chemistry, Montreal, Canada, pp. 1-3.

Buchert, J., Bergnor, E., Lindblad, G., Viikari, L., Ek, M., 1997b. Significance of xylan and glucomannan in the brightness reversion of kraft pulps. Tappi J. 80, 165171.

Clayton, D.W., 1963. The alkaline degradation of some hardwood 4-O-methyl-Dglucuronoxylans. Sven. Papperstidn. 66, 115-124.

Devenyns, J., Chauveheid, E., 1997. Uronic acids and metal control. In: Nineth International Symposium on Wood and Pulp Chemistry, Montreal, Canada, pp. $1-4$.

Elsander, A., Ek, M., Gellerstedt, G., 2000. Oxalic acid formation during ECF and TCF bleaching of kraft pulp. Tappi J. 83, 73-77.

Garozzo, D., Giuffrida, M., Impallomeni, G., Ballistreri, A., Montaudo, G., 1990 Determination of linkage position and identification of the reducing end in linear oligosaccharides by negative ion fast atom bombardment mass spectrometry. Anal. Chem. 62, 279-286.

Jiang, Z.-H., Van Lierop, B., Berry, R., 2000. Hexenuronic acid groups in pulping and bleaching chemistry. Tappi J. 83, 167-175.

Johansson, M.H., Samuelson, O., 1977. Epimerization and degradation of 2-O-(4-Omethyl-D-glucopyranosyluronic acid)-D-xylitol in alkaline medium. Carbohyd. Res. 54, 295-299.

Kantelinen, A., Hortling, B., Sundquist, J., Linko, M., Viikari, L., 1993. Proposed mechanism of the enzymatic bleaching of kraft pulp with xylanases. Holzforschung 47, 318-324.

Li, J., Gellerstedt, G., 1997. The contribution to kappa number from hexeneuronic acid groups in pulp xylan. Carbohyd. Res. 302, 213-218.

Mulroney, B., Traeger, J.C., Stone, B.A., 1995. Determination of both linkage position and anomeric configuration in underivatized glucopyranosyl disaccharides by electrospray mass spectrometry. J. Mass Spectrom. 30, 1277-1283.

Paice, M.G., Gurnagul, N., Page, D.H., Jurasek, L., 1992. Mechanism of hemicellulase directed prebleaching of kraft pulp. Enzyme Microbiol. Technol. 14, 272-276.

Saeman, J.F., Moore, W.E., Millet, M.A., 1963. In: Whistler, R.L. (Ed.), Methods in Carbohydrate Chemistry. Academic Press, New York, pp. 54-69.

Shatalov, A.A., Evtuguin, D.V., Neto, C.P., 1999. (2-O-D-Galactopyranosyl-4-Omethyl-D-glucurono)-D-xylan from Eucalyptus globulus Labill. Carbohyd. Res. 320, 93-99.

Shatalov, A.A., Pereira, H., 2000. Structure of heteroxylan from Eucalyptus globulus L. and its transformation during kraft delignification. In: 20th International Carbohydrate Symposium, Hamburg, Germany, pp. 370.

Shatalov, A.A., Pereira, H., 2001. Arundo donax L. reed: new perspectives for pulping and bleaching-2. Organosolv delignification. Tappi J. 84, 1-14.

Shatalov, A.A., Pereira, H., 2004. Uronic (hexenuronic) acid profile of ethanol-alkali delignification of giant reed Arundo donax L.. Cellulose 11, 109-117.

Shatalov, A.A., Pereira, H., 2005. Arundo donax L. reed: new perspectives for pulping and bleaching - 4. Peroxide bleaching of organosolv pulps. Biores. Technol. 96 865-872.

Shatalov, A.A., Pereira, H., 2007. Polysaccharide degradation during ozone based TCF bleaching of non-wood organosolv pulps. Carbohyd. Polym. 67, 275-281. 
Simkovic, I., Ebringerova, A., Hirsch, J., Königstein, J., 1986. Alkaline degradation of model compounds related to (4-O-methyl-D-glucurono)-D-xylan. Carbohyd. Res. 152, 131-136.

Spengler, B., Dolce, J., Cotter, R., 1990. Infrared laser desorption mass spectrometry: fragmentation mechanisms and isomer analysis. Anal. Chem. 62, 1731-1737.

Süss, H.U., Nimmerfroh, N.F., 1993. Peroxide bleaching technology. Review. Emerging Pulping and Chlorine-Free Bleaching Technologies Proceedings, Raleigh, USA.

Tolan, J.S., Olson, D., Dines, R.E., 1996. Survey of mill usage of xylanase. In: Jeffries, T.W., Viikari, L. (Eds.), Enzymes for Pulp and Paper Processing, ACS Symposium, Series, 655, pp. 25-35.
Vuorinen, T., Fagerström, P., Buchert, J., Tenkanen, M., Teleman, A., 1999. Selective hydrolysis of hexenuronic acid groups and its application in ECF and TCF bleaching of kraft pulps. J. Pulp Paper Sci. 25, 155-162.

Wong, K.K.Y., Nelson, S.L., Saddler, J.N., 1996. Xylanase treatment for the peroxide bleaching of oxygen delignified kraft pulps derived from three softwood species. J. Biotechnol. 48, 137-145.

Yang, J.L., Eriksson, K.-E.L., 1992. Use of hemicellulolytic enzymes as one stage in bleaching of kraft pulps. Holzforschung 46, 481-488.

Yang, J.L., Lou, G., Eriksson, K.-E.L., 1992. The impact of xylanase on bleaching of kraft pulps. Tappi J. 12, 95-101. 